\title{
Inquiry into Gendered Teacher-Student Classroom Interactions
}

\author{
Ra'na Malik $^{*}$ \\ Nayab Javed ${ }^{* *}$ \\ Muhammad Dilshad $^{* * *}$
}

\begin{abstract}
The present study aimed to examine the effects of teachers' gender on teacher-student interactions in the classroom. Moreover, the differences in frequency of interaction, differences in types of teacher initiatives and responses towards boys and girls in the classroom were also identified. Total 36 lessons were observed in grade $8^{\text {th }}$ classroom in a local school in Gujranwala. Each class lesson was observed for 30 minutes. Observations were coded using the Interactions for Sex Equity in Classroom Teaching (INTERSECT) observational research tool. The study found that boys received more praise from female teachers than male teachers. Moreover, both male and female teachers criticize boys more while male teachers tend to interact more with girls than boys. This paper provides guide lines to the curriculum planners to recommend gender neutral teaching techniques for the male and female teachers to be practiced in mixed gender (coed) classes.
\end{abstract}

Keywords: gender, teacher-student interaction, observation methods, INTERSECT, Pakistan

\footnotetext{
*Assistant Professor

Department of Gender Studies, Punjab University, Lahore, raana.malik@yahoo.com

${ }^{* *}$ Lecturer Department of Gender Studies Lahore College Women University, Lahore

*** Associate Prof Department of Education Baha-ud-din Zakriya University, Multan
} 


\section{Introduction}

The formation of gender identities is a complex process which includes a combination of both biological and social changes. Children start wondering about their gender identities as early as at the age of three and become fully aware of their gender identity during their early years of school. Anthropologists assumed that formation of gender identities is a part of socialization process. Among the various agents of socialization such as family, peer group, media, religion, school is one of the most important agent. The school is not only a place where students acquire worldly knowledge, but a place where they become socialized and learn to assume specific roles in the society.

Teaching and learning process is a triangle consisting of three important pillars: teacher, student and content matter. However, the most important role in this process is of teacher who works as a role model, counselor and instructor in the classroom. The classroom environment is based on the dynamic factors that affect the learning of the students. These include learning material, surroundings, curriculum, teaching strategies and most importantly the teacher. The interaction in the classroom between teacher and student occurs through verbal, gestural and resource instrumentality for effective communication. Gender is considered as an influencing factor in the classroom particularly, in accordance with the interaction between teacher and student. Although the gender of both teacher and student matters in the classroom interaction but the gender of teacher is more influencing (Sadker\& Sadker, 1992; Tannan, 1991). Gender biasness in classroom interactions occurs through many factors like teacher initiated interactions with male and female students differently, number of interactions with particular gender, number of teachers' response towards specific gender etc. (Ifegbesan, 2010).

\section{Literature Review}

Classroom interaction refers to a classroom process in which teachers and students have a reciprocal effect upon each other in what they do and say in the classroom (Matelo, 2006). Further, it can be explained as an interpersonal transaction which takes place at different levels between teacher and student both through verbal and non-verbal actions of teacher and students (Nonye and Nkadi, 2004). Classroom interaction consists of three broad categories: (a) teacher-student 
interaction/conversation in class work, (b) student to teacher discussion in classroom work, and (c) learner dialogue in group work.

The past researches done in 1960 s to recent studies undertaken after 2000, mostly indicated differential gender patterns in teachers' interactions in the classroom (Tannen, 1991; Sadker \& Sadker,1994). Many researches revealed differences on the basis of teacher initiation for example, unequal treatment on the basis of gender of students at the elementary (Bailey, 1993; Holden,1993; Hopf \& Hatzichristou, 1999), junior (Heller \& Parsons, 1981; Sadker, \& Sadker, 1994; Worrall \& Tsarna, 1987), high school (Omvig,1989; Smith, 1991) pre-college and college classrooms (Sadker \& Sadker, 1992; Tannen, 1991). Both male and female teachers askedmore questions from the boys as considering them more critical and providing them more opportunity to response in classroom, maintain more eye contact with them and called their names more than girls. Boys were also found dominating and interrupting the class more than girls (Sadker \& Sadker, 1992; Thorne, 1979; Hall, 1982; Kelly, 1988). Moreover, it was also found that classrooms were male dominated, more response given to boys with attention and boys more visible and prominent while girls invisible in classroom (Sadker, 1999; Kelly, 1988).

Studies had found the differences in interaction dependent more on the gender of teachers and partially on the subject being taught by the teachers (Hopf \& Hatzichrisou, 1999; Omvig, 1989; Worrall \&Tsarna, 1987; Sadker et al., 1994). Many studies found differences on the basis of student's response in the classrooms. Boys contribute more to classroom interactions than girls as teachers of both genders provided more opportunity to boys by asking questions to them (Meece, 1987; Francis, 2004; Duffy, et.al. 2002; Rashidi and Rafiee Rad, 2010). Chavez (2000) reported that girls create less disturbance and humor than boys in classrooms and hence, remain serious. Boys were given more individual instructions, social interactions, acknowledgment and praise, encouragement and corrective feedback (Hu, 2012). The girls received less work related criticism (Parson et al, 1980). Moreover, boys were found more restless in class than girls and such movements caught teachers' attention more (Mehran, 2003; Good et al, 1973). Boys mostly misbehavior in class and receive warnings from both male and female teachers (Mehran, 2003; Good, Looper and Blakely, 1980). Nordic research infers that male students attract teacher's attention more than females in a positive and negative sense while they were more prominent in class. Good et al, (1973) also concluded that boys were not only directed at negative feedback but also receive positive feedback by their 
teacher. Though the ratio of negative feedback was greater than positive feedback. Similarly, high ability boys were mostly favored as compared to low ability girls (Mehran, 2003). Girls mostly make individual approaches towards teachers (Good et al, 1980).

Many studies revealed that female teachers were more gender, sensitive, supportive and patient than male teachers (Brophy,1985; Meece,1987; Rashidi \& Naderi, 2012). Moreover, studies also found that female teachers interact differently like they ask more referential questions, gave more praise and less criticism than male teachers (Rashidi \& Naderi, 2012). Another study explained that female teachers were found to direct significantly more praise, acceptance, remediation and criticism towards male students than female students (Omvig, 1989).While another interesting difference found was that female teachers gave more warning about the behavioral problems of students than male teachers (Hopf \& Hatzichristou, 1999). Male teachers had been found to interact two-third of time with male students and only onethird of the time with female students. In contrast, female teachers had been found to interact with male and female students on a $51: 49 \%$ ratio (Bellamy, 1994). Regarding gender biasness, Holden (1993) reported that teachers were found less to provide applied classroom approaches to nullify gender bias.

Summing up, all these studies together is not an easy task, as, there are many differences and similarities found in the studies. Some studies have indicated gendered differential interaction of male and female teachers in their classes, whilst in some studies differences in teachers' interaction was more due to gender of students than differences in the behavior of teachers. And also some studies concluded that differences in student-teacher interaction was both due to the gender of students and teachers. However, the differences in the student-teacher interactions definitely effects the teaching-learning process in the classroom either in a positive or negative way. Moreover, gender has been defined and perceived differently across the globe and each country sees it in its own socio-cultural context. Therefore, the findings from different parts of the world can't be generalized to other contexts. Hence, there is a need to explore the differences of teachers' gender on the student-teacher interaction in a mix gender classroom in Pakistani schools. This study aims to find out how the gender of the teacher influences classroom interactions such as frequency of interactions, types of teacher initiatives and responses towards specific gender of students. 


\section{Objectives of the study}

i. Explore gender differences in teacher's response-based interactions directed towards boys and girls in classrooms;

ii. Find out the gender differences in teacher's initiative based interactions towards boys and girls in classrooms.

\section{Hypotheses}

The following hypotheses were formulated based on the teacher's response and teacher's initiative:

$\mathrm{Ho}_{1}$ : There is no difference in male and female teacher's response towards boys and girls during classroom interaction.

$\mathrm{Ho}_{1 \mathrm{a}}$ : There is no difference in male and female teachers' praise towards boys and girls during classroom interaction.

$\mathrm{Ho}_{1 \mathrm{~b}}$ : There is no difference in male and female teacher's criticism towards boys and girls during classroom interaction.

$\mathrm{Ho}_{2}$ : There are no differences in male and female teacher's initiative towards boys and girls during classroom interaction.

$\mathrm{Ho}_{2 \mathrm{a}}$ : There is no difference in male and female teachers' calling names of boys and girls during classroom interaction.

$\mathrm{Ho}_{2 \mathrm{~b}}$ : There is no difference in male and female teachers' pin pointing boys and girls during classroom interaction.

$\mathrm{Ho}_{2 \mathrm{c}}$ : There is no difference in the eye contact of male and female teachers towards boys and girls during classroom interaction.

\section{Sample}

There are hardly any coed schools after grade 5 in the public sector in Punjab. However, there are coed private schools up to secondary level. Hence, a private school was selected as a sample from Gujranwala District (Registered with the Board of Intermediate, Gujranwala) for the purpose of the study. Grade $8^{\text {th }}$ was selected for classroom observation for the reason that at this stage of age, students are at transactional period of their life cycle both physically and emotionally. They are very sensitive about themselves as well as people around them. Therefore, the researchers believe that the differential behaviors of male and female teachers may have great impact on students' learning in the classroom. The coed classes were taught both by the male and female teachers and there were almost equal number of boys and girls in the class. 


\section{Research Instrument}

The tool used for classroom observation was the Gender Equity Observation Checklist (INTERSECT) developed by Sadker et al., (1994). The tool helps to systematically observe classroom interactions and record frequency and pattern of teacher-initiated interactions to students. The INTERSECT elaborates coding teacher student interactions by (a) Teacher initiation and (b) Teacher response. Overall, classroom observation was divided into three major groups: (a) focus on teacher's interaction (b) focus on the teacher-student interactions and (c) focus on the student interactions. However, in line with the purpose of the study, researchers focused on teacher-student interactions through quantitative organized observations.

\section{Data Collection}

In total, 40 lessons (20 male and female teachers' lessons each) were observed. The class of each teacher was observed 3 times in consecutive lessons. The classroom observation duration was 30 minutes. A coobserver was also present during all sessions. The co-observer was given training by the researchers in using INTERSECT in the classroom setting. He observed a lesson in a high school along with the researcher as a pilot. The inter-rater reliability for the researcher was .76 and coobserver was .74, indicating a high inter-rater reliability. The classroom observation took place in a mixed gender (coed) high school from $10^{\text {th }}$ February to $20^{\text {th }}$ March 2017. The lessons were observed for the subjects of science, mathematics, Urdu and English. Each lesson was observed and video-taped. The researcher and co-observer were present in classroom before the arrival of the students and teacher and sit at the back and or side of the room, so as not to disturb class and been able to have a clear view of the whole setting. In addition to recording on INTERSECT, researchers also took field notes on classroom setup, teacher informal talk, and teacher behavior in the classroom.

\section{Data Analysis}

Almost1080 minutes of classroom interaction was transcribed. Codes were assigned to names to maintain participants' confidentiality. However, for data analysis 36 lessons were selected due to the degree of clearness and relevance. So, two classes were left out of analysis due to 
their low quality. Data were coded and scored following the instructions given in the INTERSECT manual. Then descriptive and inferential statistics were used to further analyze the data.

\section{Ethical Considerations}

Formal permission was taken from the school to conduct the study. Further, the purpose of the study was shared with the teachers and lessons were recorded after their consent. The codes were used to protect the anonymity of the data. While recording the teacher-student interaction on the checklist in the classroom, researcher did not write name of any particular teacher rather used codes. Further, the researchers used password protected folders to protect the recordings of the classroom observations and destroyed the recordings after completion of study.

\section{Findings}

\section{Teachers' Response: Positive and Negative}

The teachers' response was categorized as positive or negative towards students in the classroom. The positive and negative responses of teachers were further categorized into four sections as described in this section.

\section{A. Positive Response}

The positive response of teacher comes in the form of praise for students in the classroom. There can be four types of teachers' positive response (praise) in the classroom:

Praise Intellectual: teacher giving positive response academically to boys and girls;

Praise Conduct: teachers' positive comments on the conduct or behavior of boys and girls;

Praise Appearance: teacher giving positive comments regarding the appearance (dress, tidiness etc.) of boys and girls;

Praise Others: teacher showing positive attitude other than the above three types like giving smile or any kind of positive gestures to the students. 
Table 1

Frequency Distribution of Positive Response by sex of Teacher and Student

\begin{tabular}{|c|c|c|c|c|c|}
\hline \multirow[t]{2}{*}{ Teacher Response } & \multirow[t]{2}{*}{ Student } & \multicolumn{2}{|l|}{$\mathrm{N}$} & \multicolumn{2}{|c|}{$\%$} \\
\hline & & No & Yes & No & Yes \\
\hline \multirow[t]{3}{*}{$\begin{array}{l}\text { Praise Intellectual } \\
\text { (PI) } \\
\text { Male Teacher }\end{array}$} & Boys & 25 & 83 & $23.1 \%$ & $76.9 \%$ \\
\hline & Girls & 57 & 106 & $35.0 \%$ & $65.0 \%$ \\
\hline & Total & 82 & 189 & $30.3 \%$ & $69.7 \%$ \\
\hline \multirow[t]{3}{*}{ Female Teacher } & Boys & 74 & 163 & $31.2 \%$ & $68.8 \%$ \\
\hline & Girls & 52 & 162 & $24.3 \%$ & $75.7 \%$ \\
\hline & Total & 126 & 325 & $27.9 \%$ & $72.1 \%$ \\
\hline \multicolumn{6}{|l|}{ Praise Conduct (PC) } \\
\hline \multirow[t]{3}{*}{ Male Teacher } & Boys & 36 & 72 & $33.3 \%$ & $66.7 \%$ \\
\hline & Girls & 47 & 116 & $28.8 \%$ & $71.2 \%$ \\
\hline & Total & 83 & 188 & $30.6 \%$ & $69.4 \%$ \\
\hline \multirow[t]{3}{*}{ Female Teacher } & Boys & 97 & 140 & $40.9 \%$ & $59.1 \%$ \\
\hline & Girls & 76 & 138 & $35.5 \%$ & $64.5 \%$ \\
\hline & Total & 173 & 278 & $38.4 \%$ & $61.6 \%$ \\
\hline \multicolumn{6}{|l|}{$\begin{array}{l}\text { Praise Appearance } \\
(P A)\end{array}$} \\
\hline \multirow[t]{3}{*}{ Male Teacher } & Boys & 38 & 70 & $35.2 \%$ & $64.8 \%$ \\
\hline & Girls & 57 & 106 & $35.0 \%$ & $65.0 \%$ \\
\hline & Total & 95 & 176 & $35.1 \%$ & $64.9 \%$ \\
\hline \multirow[t]{3}{*}{ Female Teacher } & Boys & 89 & 148 & $37.6 \%$ & $62.4 \%$ \\
\hline & Girls & 86 & 128 & $40.2 \%$ & $59.8 \%$ \\
\hline & Total & 175 & 276 & $38.8 \%$ & $61.2 \%$ \\
\hline \multicolumn{6}{|l|}{ Praise Others (PO) } \\
\hline \multirow[t]{3}{*}{ Male Teacher } & Boys & 38 & 70 & $35.2 \%$ & $64.8 \%$ \\
\hline & Girls & 51 & 112 & $31.3 \%$ & $68.7 \%$ \\
\hline & Total & 89 & 182 & $32.8 \%$ & $67.2 \%$ \\
\hline \multirow[t]{3}{*}{ Female Teacher } & Boys & 74 & 163 & $31.2 \%$ & $68.8 \%$ \\
\hline & Girls & 46 & 168 & $21.5 \%$ & $78.5 \%$ \\
\hline & Total & 120 & 331 & $26.6 \%$ & $73.4 \%$ \\
\hline
\end{tabular}

It is worth mentioning here that during data collection, due consideration was given to the fact that boys and girlsparticipate almost equally in the classroom. Multiple observations were made to minimize the possibility of either boy or girl student participating more in the classroom due to various reasons (competence, readiness, interest etc.). Hence, the recorded observations focused on the response of male and female teachers with students.

Table 1 shows the interaction of teachers giving positive response to the students (both boys and girls) in the classroom. The male teachers gave more conduct $(69.4 \%)$ and appearance $(64.9 \%)$ praise to students as 
compared to the female teachers $(61.6 \%$ \& $61.2 \%)$, whereas female teachers gave more praise intellectual to students than male teachers $(72.1 \%$ and $69.7 \%)$. This shows that male teachers gave more compliments to students on their conduct in the classroom and appearance whist female teachers appreciate students more on their class participation.

Further analysis indicates that girls participated more in the class of female teachers $(75.7 \%)$ than male teachers $(65.0 \%)$. The reverse situation was true for boys $(76.9 \%$ vs $68.8 \%)$. In the Pakistani sociocultural context, it is very common that girls feel shy and submissive in the presence of boys in the classroom. And specifically in the presence of male teachers. The results confirmed that girls took advantage of female teachers and tries to interact more with the teacher in a mixed gender class. Both male and female teachers appreciate girls' behavior more than boys in the classroom $(71.2 \%$ and $64.5 \%$ vs $66.7 \%$ and $59.1 \%)$. Girls in the coed class take special care of their behavior and conduct. They deliberately behave in a positive manner, and don't want to be mocked in the class due to any disciplinary issue. The male teachers (64.9\%) gave more compliments as compared to female teachers (61.2\%). The female teachers gave boys (62.4\%) nice compliments more than girls $(58.8 \%)$. This shows their positive attitude to boost boys to improve their appearances. The researchers' observed that girls were mostly neat and tidy than boys. Thus, female teachers tried to be friendlier with the students and gave a push to the boys to look neater and in shape as girls.

The study also shows that both male and female teachers gave nonverbal gestures (smiling etc.) more to girls $(68.7 \%$ and $78.5 \%)$ than boys $(64.8 \%$ and $\%$ vs $68.8 \%)$. But overall female teachers were found giving more positive gestures to students as compared to males $(73.4 \%$ vs $67.2 \%$ ). It means that female teachers tried to create conducive learning environment in the classroom through non-verbal interaction with students also. One possible explanation could be that they remain in bounding with the students even when they are working in groups or doing individual class work. However, female teachers' comparatively had reserved response towards boys shows their stereotypical behavior in the Pakistani context. The students in class $8^{\text {th }}$ are in their early adolescent period, female teachers possibly are more careful in giving positive non-verbal responses to the male students. As a matter of fact, boys are mostly more rough and casual in their attitudes in the presence of female teachers whereas male teachers are very authoritative in their classes. The girls get more support from a female teacher in a coed class and that is mostly comfortably extended by the female teachers. 
Table 2

Chi Square of Positive Response by Sex of Teacher and Student

\begin{tabular}{|c|c|c|c|}
\hline Teacher Response & Student & $x$ & Sig \\
\hline \multicolumn{4}{|l|}{ Praise Intellect } \\
\hline Male teacher & Boys & 4.302 & .043 \\
\hline Female teacher & $\begin{array}{l}\text { Girls } \\
\text { Boys }\end{array}$ & 2.678 & .011 \\
\hline & \\
\hline Male teacher & $\begin{array}{l}\text { Boys } \\
\text { Girls }\end{array}$ & 6.19 & .050 \\
\hline Female teacher & $\begin{array}{l}\text { Boys } \\
\text { Girls }\end{array}$ & 5.39 & .046 \\
\hline \multicolumn{4}{|l|}{ Praise Appearance } \\
\hline Male teacher & $\begin{array}{l}\text { Boys } \\
\text { Girls }\end{array}$ & 1.98 & .000 \\
\hline Female teacher & $\begin{array}{l}\text { Boys } \\
\text { Girls }\end{array}$ & 3.29 & .029 \\
\hline Praise Others & & & \\
\hline Male teacher & $\begin{array}{l}\text { Boys } \\
\text { Girls }\end{array}$ & 4.47 & .050 \\
\hline Female teacher & $\begin{array}{l}\text { Boys } \\
\text { Girls }\end{array}$ & 5.45 & .025 \\
\hline
\end{tabular}

The Chi-square analyses were conducted to find out whether difference in the occurrence of positive interaction of male and female teachers with boys and girls in the classroom were significant or not. All the difference between male and female teachers' positive interaction were found affected by the gender of the teacher. The male and female teachers gave praise in intellect, conduct and appearance to boys and girls in different ways.

\section{B. Negative Response}

The criticism by the teacher towards both boys and girls in the classroom, is termed as 'negative response'. There are four types of teachers' negative responses:

Criticism Intellectual: teacher give negative response academically to the boys and girls;

Criticism Conduct: teachers give negative comments on the conduct or behavior of the boys and girls;

Criticism Appearance: teachers give negative response regarding the appearance (dress code etc.) of boys and girls; 
Criticism Others: teachers give criticism other than the above three types (making faces).

Table 3 shows that overall female teachers gave more warning to students (both boys and girls) in the classroom than the male teachers. This could be observedin all the types of negative interaction categories expect intellectual criticism. Boys received more negative criticism both from male and female teachers on giving wrong answers or not participating than girls in the classroom. The study observed that girls were attentive and participated more often than boys in

Table 3

Frequency Distribution of Negative Response by Gender of Students and Teachers

\begin{tabular}{|c|c|c|c|c|c|}
\hline $\begin{array}{l}\text { Teacher } \\
\text { Response } \\
\text { No } \\
\end{array}$ & Student & $\mathrm{N}$ & \multicolumn{3}{|c|}{$\%$} \\
\hline \multicolumn{6}{|l|}{$\begin{array}{l}\text { Criticism } \\
\text { Intellectual (CI) }\end{array}$} \\
\hline \multirow[t]{3}{*}{ Maleteacher } & Boys & 31 & 77 & $28.7 \%$ & $71.3 \%$ \\
\hline & Girls & 53 & 110 & $32.5 \%$ & $67.5 \%$ \\
\hline & Total & 84 & 187 & $31.0 \%$ & $69.0 \%$ \\
\hline \multirow[t]{3}{*}{ Femaleteacher } & Boys & - & - & $31.2 \%$ & $68.8 \%$ \\
\hline & Girls & 78 & 136 & $36.4 \%$ & $63.6 \%$ \\
\hline & Total & 152 & 299 & $33.7 \%$ & $66.3 \%$ \\
\hline \multicolumn{6}{|c|}{ Criticism Conduct (CC) } \\
\hline \multirow[t]{3}{*}{ Maleteacher } & Boys & 31 & 77 & $28.7 \%$ & $71.3 \%$ \\
\hline & Girls & 58 & 105 & $35.6 \%$ & $64.4 \%$ \\
\hline & Total & 89 & 182 & $32.8 \%$ & $67.2 \%$ \\
\hline \multirow[t]{3}{*}{ Femaleteacher } & Boys & 61 & 176 & $25.7 \%$ & $74.3 \%$ \\
\hline & Girls & 65 & 149 & $30.4 \%$ & $69.6 \%$ \\
\hline & Total & 126 & 325 & $27.9 \%$ & $72.1 \%$ \\
\hline \multicolumn{6}{|c|}{ Criticism Appearance (CA) } \\
\hline \multirow[t]{3}{*}{ Maleteacher } & Boys & 49 & 59 & $45.4 \%$ & $54.6 \%$ \\
\hline & Girls & 53 & 110 & $32.5 \%$ & $67.5 \%$ \\
\hline & Total & 102 & 169 & $37.6 \%$ & $62.4 \%$ \\
\hline \multirow[t]{3}{*}{ Femaleteacher } & Boys & 79 & 158 & $33.3 \%$ & $66.7 \%$ \\
\hline & Girls & 65 & 149 & $30.4 \%$ & $69.6 \%$ \\
\hline & Total & 144 & 307 & $31.9 \%$ & $68.1 \%$ \\
\hline \multicolumn{6}{|c|}{ Criticism Others (CO) } \\
\hline \multirow[t]{3}{*}{ Maleteacher } & Boys & 28 & 80 & $25.9 \%$ & $74.1 \%$ \\
\hline & Girls & 59 & 104 & $36.2 \%$ & $63.8 \%$ \\
\hline & Total & 87 & 184 & $32.1 \%$ & $67.9 \%$ \\
\hline \multirow[t]{3}{*}{ Femaleteacher } & Boys & 76 & 161 & $32.1 \%$ & $67.9 \%$ \\
\hline & Girls & 68 & 146 & $31.8 \%$ & $68.2 \%$ \\
\hline & Total & 144 & 307 & $31.9 \%$ & $68.1 \%$ \\
\hline
\end{tabular}


the classroom. The male teachers gave more warning to both boys and girls than female teachers $(71.3 \%$ and $67.5 \%$ vs $68.8 \%$ and $63.6 \%$, respectively). Again, boys were criticized more than girls for their inappropriate behavior in the classroom. The female teachers were found more disciplined and were very critical of any misbehavior in classroom and they were stricter with boys (74.3\% and $69.6 \%)$. The boys generally showed more causal behavior when female teachers were around as male teachers were more authoritative and strict in class.

The girls received more warnings both from male and female teachers on their appearance. This is very obvious that in a mix gender class, teachers are more sensitive regarding girls' appearance, particularly, when they are at the onset of their puberty age. The nonverbal negative interaction by the male teachers was more towards boys (74.1\%) as compared to girls $(63.8 \%)$. Boys mostly behave properly in the class in the presence of male teachers. The study clearly shows that both male and female teachers don't let boys dominate the class and were very strict in their behavior towards boys. The girls were given space to participate in the classroom activities.

Table 4

Chi Square of Negative Response by Sex of Teacher and Student

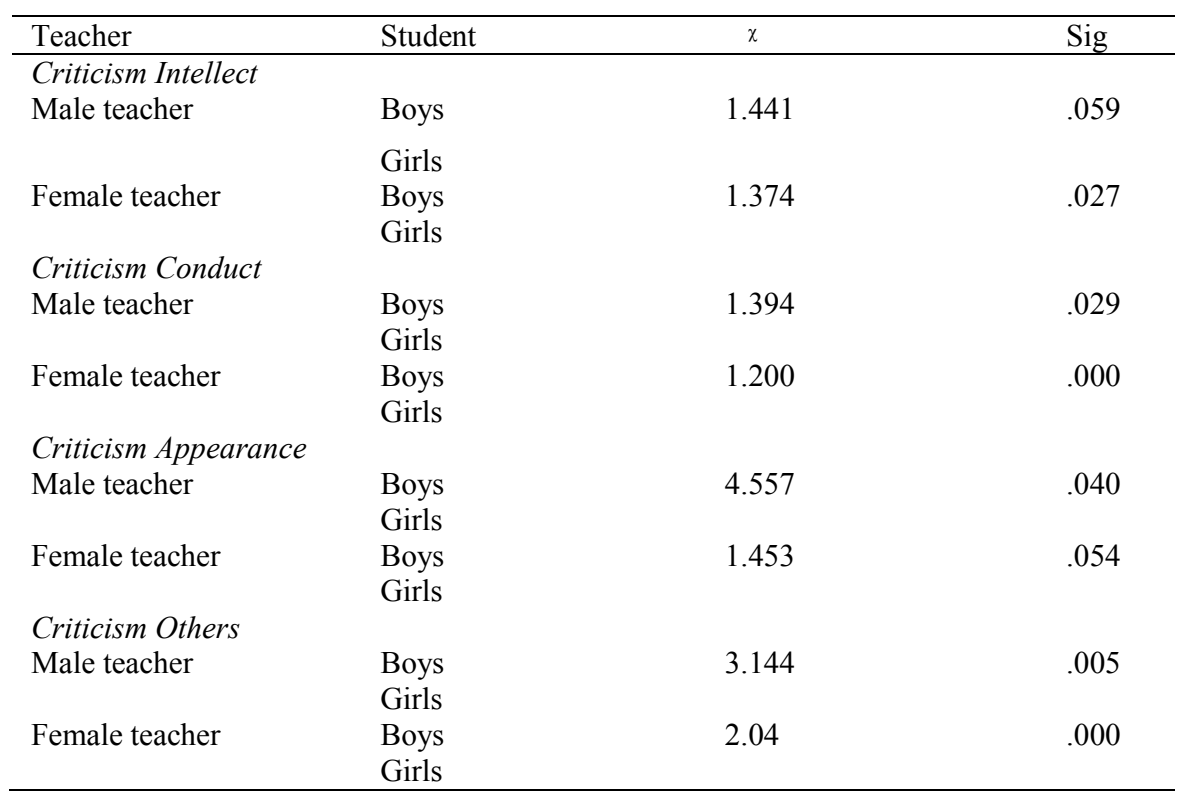


The Chi-square analyses was conducted to find out whether difference in the occurrence of negative interaction of male and female teachers with boys and girls in the classroom were significant or not. All the difference between male and female teachers' negative interaction were found affected by the gender of the teacher. The male and female teachers gave warnings and criticize boys and girls in different ways.

\section{Teacher Initiation}

The teacher initiation includes any type of interaction initiated towards students by the teacher in the classroom. It includes both verbal and nonverbal interactions like calling names of students or pin pointing to make them attentive, maintaining eye contact etc. The table below shows the interaction initiated by female and male teachers with boys and girls in the classroom. The observations were recorded both on the verbal and one non-verbal interactions, separately.

Table 5

Frequency Distribution of Teacher Initiates by Sex of Teacher and Student

\begin{tabular}{|c|c|c|c|c|c|}
\hline Teacher & Student & $\mathrm{N}$ & & $\%$ & \\
\hline & & No & Yes & No & Yes \\
\hline \multicolumn{6}{|l|}{ Call Name } \\
\hline \multirow[t]{2}{*}{ Male Teacher } & Boys & 31 & 77 & $28.7 \%$ & $71.3 \%$ \\
\hline & Girls & 43 & 120 & $26.4 \%$ & $73.6 \%$ \\
\hline \multirow{4}{*}{$\begin{array}{l}\text { Female } \\
\text { Teacher }\end{array}$} & Total & 74 & 197 & $27.3 \%$ & $72.7 \%$ \\
\hline & Boys & 37 & 200 & $15.6 \%$ & $84.4 \%$ \\
\hline & Girls & 32 & 182 & $15.0 \%$ & $85.0 \%$ \\
\hline & Total & 69 & 382 & $15.3 \%$ & $84.7 \%$ \\
\hline \multirow{3}{*}{$\begin{array}{l}\text { Point Out } \\
\text { Male Teacher }\end{array}$} & Boys & 34 & 74 & $31.5 \%$ & $68.5 \%$ \\
\hline & Girls & 35 & 128 & $21.5 \%$ & $78.5 \%$ \\
\hline & Total & 69 & 202 & $25.5 \%$ & $74.5 \%$ \\
\hline \multirow{3}{*}{$\begin{array}{l}\text { Female } \\
\text { Teacher }\end{array}$} & Boys & 60 & 177 & $25.3 \%$ & $74.7 \%$ \\
\hline & Girls & 45 & 169 & $21.0 \%$ & $79.0 \%$ \\
\hline & Total & 105 & 346 & $23.3 \%$ & $76.7 \%$ \\
\hline \multirow{4}{*}{$\begin{array}{l}\text { Eye Contact } \\
\text { Male Teacher }\end{array}$} & & & & & \\
\hline & Boys & 21 & 87 & $19.4 \%$ & $80.6 \%$ \\
\hline & Girls & 29 & 134 & $17.8 \%$ & $82.2 \%$ \\
\hline & Total & 50 & 221 & $18.5 \%$ & $81.5 \%$ \\
\hline \multirow{3}{*}{$\begin{array}{l}\text { Female } \\
\text { Teacher }\end{array}$} & Boys & 30 & 207 & $12.7 \%$ & $87.3 \%$ \\
\hline & Girls & 26 & 188 & $12.1 \%$ & $87.9 \%$ \\
\hline & Total & 56 & 395 & $12.4 \%$ & $87.6 \%$ \\
\hline
\end{tabular}


The female teachers initiated interaction (both verbal and nonverbal) more than the male teachers in the classroom. Overall, female teachers called names of students (boys and girls) more than male teachers $(84.7 \%$ vs $72.7 \%)$. However, the frequency of calling names of boys and girls was almost same $(84.4 \%$ vs $85.0 \%)$ by female teachers whilst the male teachers focused more on girls than boys $(73.6 \%$ vs $71.3 \%$ ).This wide difference shows that female teachers engaged more with students in the classroom. Calling students with their names also shows a personal bounding with them. Female teachers memorize student's names more than male teachers to create affectionate bounding with the students. The male teachers pointed out more towards boys whilst the reverse was true for female teachers. Overall, eye contact was also maintained more by the female teachers as compared to the male teachers $(87.6 \%$ vs $81.5 \%)$. Again, eye contact with the student gave a message of individualized attention and affection. The female teachers had almost same eye contact with boys and girls (87.3\% and 87.9\%), whereas, male teachers had a slightly more eye contact with the girls than boys $(82.2 \%$ vs $80.6 \%)$. This again shows a positive response of male teachers towards girls, giving them confidence and encouragement to participate in classroom.

Table 6

Chi Square of Teacher Initiates by Sex of Teacher and Student

\begin{tabular}{|c|c|c|c|c|}
\hline Teacher Response & Student & $\chi$ & & Sig \\
\hline Call Name & & & & \\
\hline Male teacher & $\begin{array}{l}\text { Boys } \\
\text { Girls }\end{array}$ & 1.77 & & .057 \\
\hline Female teacher & $\begin{array}{l}\text { Boys } \\
\text { Girls }\end{array}$ & 3.80 & & .059 \\
\hline Point Out & & & & \\
\hline Male teacher & $\begin{array}{l}\text { Boys } \\
\text { Girls }\end{array}$ & 3.42 & & .020 \\
\hline Female teacher & $\begin{array}{l}\text { Boys } \\
\text { Girls }\end{array}$ & 1.15 & & .031 \\
\hline Eye Contact & & & & \\
\hline Male teacher & $\begin{array}{l}\text { Boys } \\
\text { Girls }\end{array}$ & & 1.18 & .055 \\
\hline Female teacher & $\begin{array}{l}\text { Boys } \\
\text { Girls }\end{array}$ & & 2.07 & .028 \\
\hline
\end{tabular}

The Chi-square analyses was conducted to find out whether difference in the interaction initiated by the male and female teachers with boys and girls in the classroom was significant or not. All the 
differences between male and female teachers' initiated interaction were found affected by the gender of the teacher. The male and female teachers call names, point out and had eye contacts with boys and girls in different ways.

\section{Discussion and Conclusion}

This present observational study revealed the differences in interactions in a high school classroom because of teacher and student gender. The findings shows that teachers were actively engaged in producing and reproducing gender in the classroom through interactions which reveal the embeddedness of gender both in school culture and in the wider systems of meaning in the society. However, with regard to teachers' positive response, the study found that male teachers gave more praise to girls in their conduct and appearance and to boys in intellect. Whilst female teachers gave praise intellectual, and conduct more to girls and praise appearance to boys in the classroom. Further, female teachers praised students more for class participation than male teachers. The study shows girls receiving equal importance in the coed classes by both male and female teachers. However, female teachers were found giving more support to girls in mixed gender class. This clearly indicates that in Pakistan, teachers are fully aware of the cultural sensitivity of studying in a coed class and tries to create gender balance in the classroom. This finding is in contradiction to most of the previous researches, which indicated that boys receive more praise from female and male teachers and mostly dominate coed classes (Duffy et al.,2002; Hassaskhah \& Zamir,2013, and $\mathrm{Hu}, 2012$ ). In the Pakistani context, in a coed class, the girls particularly, at the high school level, mostly feel more confident and assertive in the presence of female teachers as compared to male teachers. Their participation in the class gets dominated by boys. The girls had lower academic achievement than boys in a coed class (Malik, 2011). Further, the general conduct of the girls in the coed class remains very careful and composed. The present study also confirms that girls received more praise on their conduct both from the male and female teachers. The boys, however, received more praise from male teachers. The high school boys take less pressure from female teachers but remain more disciplined in the classes of male teachers. The male teachers are more authoritative in their classes.

The female teachers were observed more critical in their interactions with the students as compared to male teachers. However, boys were more criticized both by male and female teachers. The boys being more 
rough and casual in their attitude might get more warnings from teachers. In appearance, male teachers were more critical towards girls in the coed class. The boys in our culture are given leverage in their conduct and behavior whereas girls are always thought to behave more responsibly and carefully. However, the female teachers took more notice of boys' behavior in the classroom than of girls. This finding is consistent with previous studies (Hassaskhah \& Zamir, 2013; Duffy, 2002, Omvig, 1989; Smith, 1992). The higher number of criticism-intellectual interactions with boys by both male and female teachers could also be taken as a type of feedback for the thinking of males. Sadker et al. (1994) found similar results in Junior high schools. They found that male students received more criticism-intellectual interactions than do female students, and that male students received more and harsher criticism for classroom misbehavior.

Female teachers tried to be friendlier and affectionate with the students whereas male teachers had more authoritative behavior in the classroom. Interestingly, male teachers initiated more talks towards girls either it was calling names, pointing out or having eye contact. Female teachers initiated almost equal talks with girls and boys. This finding is again not consistent with some of the previous studies. Female teachers directed more interactions towards boys than girls (Duffy, 2002; Bailey, 1993; Hopf \& Hatzichristou, 1999). This was also true at junior level (Heller \& Parsons, 1981; Sadker, 1992; Sadker et al.,1994) and high school level (Robinson, 1992; Smith, 1992). In the Pakistani sociocultural context, female teachers generally are reserved and conscious in a coed $8^{\text {th }}$ class. The female teachers don't want the classroom to be male dominated by calling their names more or having more eye contact. The study observed that both male and female teachers tried to create gender balance in the classroom by giving more importance to girls. In a coed class, girls are submissive and shy (Malik, 2011).

This study concludes that both male and female teachers gave space and opportunity to girls in a mixed gender classroom. The boys tried to dominate and interact more with the teachers. Even if they don't know answer, even then they will respond. Thus, teachers had more interaction with the boys. But, female teachers, particularly, tried to push girls and interact with them. Or put it another way, girls respond and participate more in the presence of female teachers. Thus, gender of the teacher does has impact on the classroom interaction-both verbal and non-verbal.

In conclusion, definitely gender is not the only factor effecting classroom interactions. Tannen (1996) rightly stated there are a lot more factors influencing classroom interaction like students' age, family 
background, competence, personality etc. It is rather impossible to eliminate differences in a classroom due to gender of both teacher and students. As Jones (2004) puts it that the differential treatment with the girls and boys in a classroom could be decreased if teachers see the video recording of their lectures. Thus, gender plays and will play an important role in the classroom interactions between teachers and students. 


\section{References}

Bailey, S. M. (1993). The current status of gender equity research in American schools. Educational Psychologist, 28, 321-339.

Brophy, J. (1985). Interactions of male and female students with male and female teachers. In L. C. Wilkinson \& C. B. Marrett (Eds.), Gender influences in classroom interaction (pp. 115-142). Orlando, FL: Academic Press.

Bellamy, N. (1994). Bias in the classroom: Are we guilty? Science Scope, 17, 60-63.

Campbell, P. B. \& Sanders, J. (1997). Uninformed but interested: Findings of a national survey on gender equity in preservice teacher education. Journal of Teacher Education, 48 (1), 69-75.

Chavez, M. (2000). Teacher and student gender and peer group gender composition in German foreign language classroom discourse: An exploratory study. Journal of Pragmatics, 32, 1019-1058

Duffy, J., Warren, K. and Walsh, M.(2002). Classroom interactions: Gender of teacher, gender of student, and classroom subject. Sex roles, $45(9 / 10), 579$ - 593

Francis, B. (2004). Classroom interaction and access: Whose space is it? In Gender in Education: A Fresh Approach, H. Claire (Ed), 42-49. London: Association of Teachers and Lecturers.3-19

Good, T. L., Sikes, J., \& Brophy, J. (1973). Effects of teacher gender and student gender on classroom interaction. Journal ofEducational Psychology, 65, 74-87.

Good, T.L., Cooper, H. M. \& Blakey, S.L. (1980). Classroom interaction as a function of teacher expectations, student sex and time of year. Journal of Educational Psychology, 72, 378-385.

Hopf, D. and Hatzichristou, C. (1999). Teacher-gender related influences in Greek schools. British Journal of Educational Psychology, 69, 118.

Holden, C. (1993). Giving girls a chance: Patterns of talk in co-operative group work. Gender and Education, 5, 179-189 
Heller, K. A., \& Parsons, J. E. (1981). Sex differences in teacher's evaluative feedback and students' expectancies for success in mathematics. Child Development, 52, 1015-1019.

Hu,W.(2012). Gendered EFL classroom interaction-A case study in a senior middle school in China. Theory and Practice in Language Studies, 2 (9). 1818-1827. doi:10.4304/tpls.2.9.1818-1827.

Ifegbesan, A. (2010). Gender-stereotypes belief and practices in the classroom: The Nigerian post-primary school teachers. Global Journal of Human Social Science Research, 10, 29-38.

Jones, S. M., \& Dindia, K. (2004) A meta-analytic perspective on sex equity in the classroom. Review of Educational Research, 74 (4), 443-471.

Malik, Ra'ana (2011). Gender differences in the academic achievement and personality development of students in single-sex and coeducational primary schools. Unpublished Thesis, University of the Punjab, Lahore.

Matelo, A. (2006). Describing Classroom Interaction. Retrieved on Line File://C: /Documents $\% 20$ and $\% 20$ setting/administrator my\%20 documents/ untitled html.

Mehran, G. (2003). Gender and education in Iran. Paper commissioned for the EFA Global Monitoring Report 2003/4, The Leap to Equality.

Meece, J. L. (1987). The influence of school experiences on the development of gender schemata. In L. S. Liben \& M. L. Signorella (Eds.), Children's gender schemata. (pp. 57-73). San Francisco, CA: Jossey-Bass

Nonye,O. E., \& Nkadi.O.(2004).Interaction patterns in Nigerian senior secondary school practical biology classroom.

Omvig, C.P. (1989). Teacher-student classroom interaction in vocational education. Kentucky: Department of Vocational Education. College of Education, University of Kentucky. ED 342943.

Parsons, J. E., Adler, T., Fulterman, R. Goff, S., Kalzala, C., Mecce, J., \& Midgley, C. (1980). Self

Perceptions, tasks, perceptions, and academic choice origins and change (Final report grant NIE-G-78-0022).Ann Arbor : University of Midigan. 
Rashidi, N. and Rafiee Rad, M. (2010). Analyzing patterns of classroom interaction in EFL classrooms in Iran. The Journal of Asia TEFL, 7(3), 93-120

Rashidi, N \& Nader, S. (2012). The effect of gender on the patterns of classroom interaction. Education, 2(3).

Sadker, M. \& Sadker, D. (1994). Still failing at fairness: How our schools cheat girls. NY: Simon \& Schuster.

Sadker, M., Sadker, D., \& Klein, S. (1992). The issue of gender in elementary and secondary education. Review of Research in Education, 17, 269-334.

Smith, D. (1991). Classroom interaction and gender disparity in secondary vocational instruction. The Journal of Vocational Education Research, 16, 35-58.

Smith, D.G.(1992). A description of classroom interaction and gender disparity in secondary business education instruction. Delta Pi Epsilon Journal, 34, 183-193.

Tannen, D. (1991). Teachers' classroom strategies should recognize that men and women use language differently. The chronicle of higher education. 17, (40).

Thorne, B. (1979). Claiming verbal space: Women, speech and language for college classrooms. Paper presented at the Research Conference on Educational Environments and the Undergraduate Woman, Wellesley College, Wellesley, MA.

Worrall, N., \& Tsarna, H. (1987). Teachers' reported practices towards girls and boys in science and languages. British Journal of Educational Psychology, 57, 300-312

\section{Citation of this Article:}

Malik, R., Javed, N., \& Dilshad, M. (2018.Inquiry into gendered teacherstudent classroom interactions. Pakistan Journal of Education, 35(1), 97116.

Received on: February 22, 2018

Revised on: June 18,2018

Accepted on: July $\quad 12,2018$ 